\title{
Antitumor Cannabinoid Chemotypes: Structural Insights
}

\author{
Paula Morales * and Nadine Jagerovic * \\ Instituto de Quimica Medica, Consejo Superior de Investigaciones Cientificas, Madrid, Spain
}

Cannabis has long been known to limit or prevent nausea and vomiting, lack of appetite, and pain. For this reason, cannabinoids have been successfully used in the treatment of some of the unwanted side effects caused by cancer chemotherapy. Besides their palliative effects, research from the past two decades has demonstrated their promising potential as antitumor agents in a wide variety of tumors. Cannabinoids of endogenous, phytogenic, and synthetic nature have been shown to impact the proliferation of cancer through the modulation of different proteins involved in the endocannabinoid system such as the G protein-coupled receptors CB1, CB2, and GRP55, the ionotropic receptor

OPEN ACCESS

Edited by:

Marialessandra Contino, University of Bari Aldo Moro,

Reviewed by: Stephen Paul Alexander, University of Nottingham, United Kingdom Maria Grazia Morgese, University of Foggia,

Italy

*Correspondence: Nadine Jagerovic nadine@iqm.csic.es Paula Morales paula.morales@iqm.csic.es

Specialty section:

This article was submitted to Experimental Pharmacology and Drug Discovery,

a section of the journal Frontiers in Pharmacology

Received: 28 February 2019 Accepted: 15 May 2019

Published: 31 May 2019

Citation:

Morales $P$ and Jagerovic $N$ (2019) Antitumor Cannabinoid Chemotypes: Structural Insights.

Front. Pharmacol. 10:621. doi: 10.3389/fphar.2019.00621 TRPV1, or the fatty acid amide hydrolase (FAAH). In this article, we aim to structurally classify the antitumor cannabinoid chemotypes described so far according to their targets and types of cancer. In a drug discovery approach, their in silico pharmacokinetic profile has been evaluated in order to identify appropriate drug-like profiles, which should be taken into account for further progress toward the clinic. This analysis may provide structural insights into the selection of specific cannabinoid scaffolds for the development of antitumor drugs for the treatment of particular types of cancer.

Keywords: cannabinoid, cancer, ADMET, in silico, chemotype

\section{INTRODUCTION}

During these last years, significant research has been focused on the therapeutic potential of cannabinoids to manage palliative effects in cancer patients (Badowski, 2017; Guzmán, 2018). Cancer-induced emesis represents the initial target indication for Marinol ${ }^{\circledR}$ (dronabinol) and Cesamet $^{\circledR}$ (nabilone), two cannabis-based medicines approved by various regulatory drug agencies. Management of cancer-induced neuropathic pain is also part of the palliative applications of cannabis-based medicines. Besides such palliative applications, some cannabinoids have shown anticancer properties (Guzmán, 2003; Guindon and Hohmann, 2011; Khan et al., 2016; Hinz and Ramer, 2019). As widely reported in the last decades, some cannabinoids are able to modulate different cellular signaling pathways implicated in cancer cell proliferation, migration, or death (Chakravarti et al., 2014). Even though the underlying mechanisms are not totally unraveled, there is significant evidence for the involvement of at least four mechanisms: direct inhibition of transformed-cell growth through the suppression of mitogenic signal, induction of apoptosis, inhibition of tumor angiogenesis, and metastasis (Velasco et al., 2016). The signaling pathways implicated in the activation of the endocannabinoid system may differ depending on specific cancers and/or experimental models, making more complex the understanding of these processes. So far, only few clinical data on the efficacy of cannabinoids as anticancer agents have been provided (Ladin et al., 2016). However, great efforts are currently being made to elucidate the potential utility of cannabinoids as anticancer therapeutics. 
The physiological processes triggered by most of these cannabinoids are mediated by two $G$ protein-coupled cannabinoid receptors (CBR), $\mathrm{CB} 1 \mathrm{R}$ and $\mathrm{CB} 2 \mathrm{R}$. $\mathrm{CB} 1 \mathrm{R}$ is predominantly and abundantly expressed in the central nervous system, with predominance in the hippocampus, cerebellum, basal ganglia, and cortical and olfactory regions, but CB1R is also present in many organs of the peripheral system. CB2R is mainly found in the immune system, in the spleen, thymus, lymph nodes, and tonsils, but it is also expressed in immune cells.

The overexpression of CBR and elevated endocannabinoid levels have been reported in different cancer types (Blázquez et al., 2006; Pisanti et al., 2013). This expression in cancer cells is crucial for downstream signaling with implications on cell viability.

Non-CB1R, non-CB2R targets related to the endocannabinoid system have also been reported to be involved in the anticancer action of cannabinoids. For instance, specific effects may be due to interactions with enzymes of the endocannabinoid system such as FAAH (fatty acid amide hydrolase), NAPEPLD ( $N$-acyl phosphatidylethanolamine phospholipase D), MAGL (monoacylglycerol lipase), DAGL (diacylglycerol lipase), ABHD6 ( $\alpha / \beta$-hydrolase domain containing 6$)$, or ABHD12 $(\alpha / \beta$ hydrolase domain containing 12); with GPR55 and/or GPR18, two putative cannabinoid orphan $G$ protein-coupled receptors; with transient receptor potential (TRP) channels (TRPV1-4, TRPM8, and TRPA1); or with COX-2 (cyclooxygenase-2), among others (Morales et al., 2017a; Morales and Reggio, 2017).

Focusing on a drug discovery approach, herein we have summarized the anticancer profiling of the cannabinoids reported thus far to impact cancer. Moreover, we have calculated their in silico pharmacokinetic profiles in order to predict appropriate drug-like profiles that may provide useful criteria for further development selection. In silico prediction of pharmacokinetic properties is a very useful approach that provides a great translational tool since absorption, distribution, metabolism, excretion, and toxicity (ADMET) properties and bioavailability of drugs can strongly influence their development (Di et al., 2018).

\section{CANNABINOIDS WITH ANTICANCER POTENTIAL}

Molecules that modulate the endocannabinoid system are considered cannabinoids. These compounds generally have been classified following their structural nature or origin. Thus, they all belong to phytogenic-, endogenous-, or synthetic-derived families.

\section{Endocannabinoids}

Endogenous cannabinoids, called endocannabinoids, such as anandamide (AEA) and 2-arachidonoyl glycerol (2-AG), form a major family of cannabinoids (Ligresti et al., 2016). Structurally, they are lipid-based derivatives derived from arachidonic acid. They are involved in a number of physiological processes but are also easily degraded through enzymatic pathways. AEA is known to affect cancer cell proliferation; however, there are cell lines whose proliferation is more sensitive to anandamide than others. The molecular mechanism of action differs also from one cell line to another. For instance, AEA exerts a potent CB1R-mediated effect on the proliferation of MCF-7, and EFM10 human breast cancer cells (Di Marzo et al., 1998), while in N18TG2 murine neuroblastoma cells, the effect is due to FAAHmediated degradation of AEA to ethanolamine (Matas et al., 2007). Another example concerns non-melanoma skin cancer, for which AEA induces endoplasmic reticulum stress and apoptosis mediated by oxidative stress and by CBR-independent endocannabinoid signaling (Soliman and Van Dross, 2016).

(R)-Methanandamide (Met-AEA, Table 1) has been used in diverse biological assays as a metabolic stable anandamide analogue. One of the first assays in cancer concerns prostate LNCaP cells (Sánchez et al., 2003).

The anandamide synthetic analogue arachidonyl-2'chloroethylamide (ACEA, Table 1) is a CB1R-selective compound, active in breast cancer stem cell invasiveness (Mohammadpour et al., 2017) but inactive in Kaposi's sarcoma cells (Luca et al., 2009).

From a series of linolenic and arachidonic derivatives, $\mathbf{4 g}$ and 5c (Table 1) enhance AEA cytotoxicity on C6 glioma cell viability (Quintana et al., 2016). Both of them incorporate the same alkanolamine moiety in their structure.

\section{Phytocannabinoids}

The plant-derived family is exemplified by the phytocannabinoids tetrahydrocannabinol [(-)- $\left.\left.\Delta^{9}-\mathrm{THC}\right) ; \mathrm{THC}\right]$ and cannabidiol [(-)-CBD; CBD], the two main components of Cannabis sativa. Structural modifications of THC mainly have been developed in the Makriyannis laboratory some years ago (Thakur et al., 2005). Concerning CBD, a recent review dedicated to CBD as scaffold provides an overview of the chemical structure of natural and synthetic derivatives, including their relative molecular targets (Morales et al., 2017b). Reports on anticancer effects of phytocannabinoids mainly have been focused on the activity of $\Delta^{9}$-THC, CBD, $\Delta^{9}$-tetrahydrocannabinolic acid ( $\Delta^{9}$-THCA), cannabidiolic acid (CBDA), cannabigerol (CBG), and cannabichromene (CBC) (Table 1) (Guzmán, 2003; Velasco et al., 2012; Fowler, 2015; Hinz and Ramer, 2019; Pellati et al., 2018). The effects of $\Delta^{9}$-THC have been tested in different cell lines of prostate cancer, breast cancer, colon cancer, pancreatic cancer, lymphoma, lung cancer, glioblastoma, and myeloma, among others (Fowler, 2015; Fraguas-Sánchez et al., 2016). Intracellular signaling through CBR has been shown to play an important role in these effects, involving complex signal transduction pathways, for instance, the ceramide pathway and/ or the PI3-K and ERK pathways. However, the mechanism of action of $\Delta^{9}$-THC can also result in being CBR-independent, as has been shown for leukemic cell lines (Powles et al., 2005).

The nonpsychoactive cannabinoid CBD revealed proapoptotic effects in different cancer cell lines (Hinz and Ramer, 2019). $\mathrm{CBR}$ activation is not required for $\mathrm{CBD}$ anticancer action since $\mathrm{CBD}$ shows very low affinity. Accumulation of reactive oxygen species (ROS) is one of the main reported mechanism responsible for apoptosis induced by CBD (Ligresti, 2006). However, several molecular targets have been suggested, such 
Endocannabinoids and derivatives<smiles>CCCCC/C=C\C/C=C\C/C=C\C/C=C\CCC(=O)NCCO</smiles>

AEA

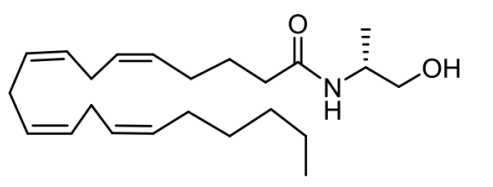

Met-AEA
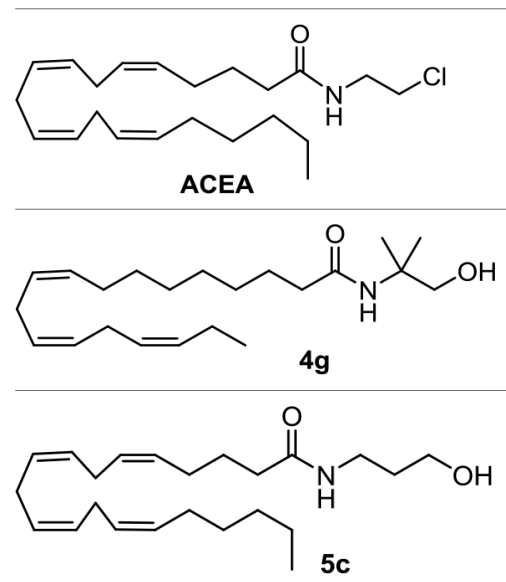

Glioma: C6 cells

Non-melanoma skin cancer: JWF2 cells

Breast cancer: MCF-7 and EFM-10 cells

Neuroblastoma: N18TG2 cells Prostate cancer: PC-3 cells

Gastric cancer: human AGS adenocarcinom

cells

Prostate cancer: LNCaP

Breast cancer: MDA-MB-231

Breast cancer: MDA-MB-231 cells
Induces apoptosis mediated by oxidative stress and by CB receptorindependent endocannabinoid signaling

Blocks cancer proliferation through CB1R-mediated inhibition of endogenous prolactin action

Neuroprotection from apoptosis mediated by FAAH Inhibits cancer cell proliferation via CB1R

(Matas et al., 2007) Apoptosis induction

Upregulation of androgen receptor expression Inhibition of cell adhesion and migration

(Ortega et al., 2016)

(Sánchez et al., 2003) (Grimaldi et al., 2006)

\section{Phytogenic compounds}

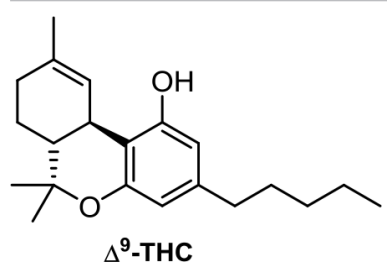

Endometrial cancer: HEC-1B and An3ca cells

Inhibits metastasis by targeting matrix MMP9

Inhibits cell proliferation, enhancing AEA cytotoxicity (via FAAH

(Quintana et al., 2016) inhibition)

Inhibits cell proliferation, enhancing AEA cytotoxicity (via FAAH

(Quintana et al., 2016) inhibition

Breast cancer: MDA-MB-231, MCF-7

Prostate cancer: PC-3 cells

Glioma: human GBM tumor samples

Leukemia: CEM, HEL-92, and HL60 cells
Induces apoptosis

Induces cell death and apoptosis

Reduces tumor growth
(Zhang et al., 2018b)

(Ligresti, 2006)

(Ruiz et al., 1999)

(Velasco et al., 2016; Dumitru

et al., 2018; López-Valero

et al., 2018)

(Powles et al., 2005) 


\section{Compound}

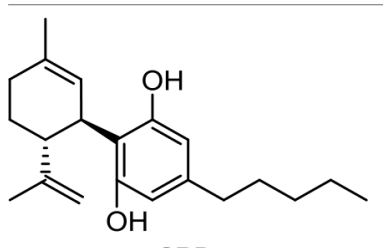

CBD

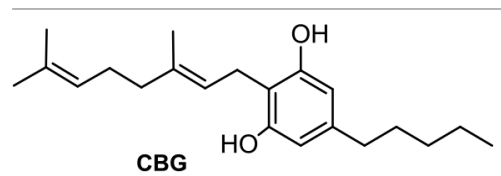

CBG

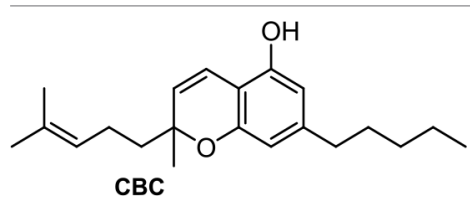

СвC
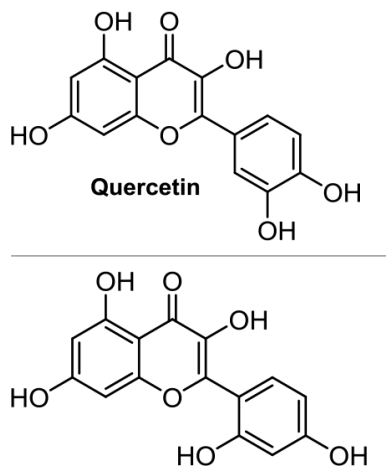

Morin

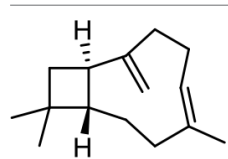

BCP

\section{Targeted tumor}

Breast cancer: MDA-MB-231, MCF-7

Prostate cancer: $\mathrm{LNCaP}$ cells

Glioma: glioma stem cells

Breast cancer: MDA-MB-231, MCF-7

Breast cancer: MDA-MB-231, MCF-7

Prostate cancer: DU-145 and LNCaP cells

Induces apoptosis, inhibiting cell viability

Inhibits cell proliferation

Ligresti, 2006

(De Petrocellis et al., 2013)

Colon cancer: Caco-2 and DLD-1 cells

Proapoptotic effects mediated through CB1R

(Refolo et al., 2015)

inger et al., 2015; Hinz and

Ramer, 2019)

(Ligresti, 2006)

Suppresses astrocyte activation and neuro-inflammation in bone

(Jiang et al., 2017) 
Synthetic cannabinoids

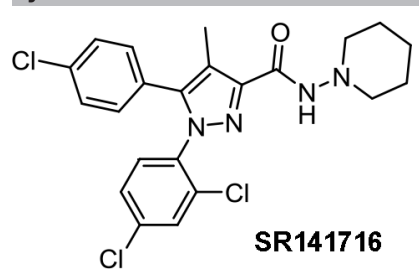

(N)

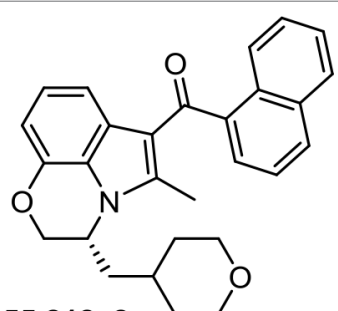

WIN 55,212-2

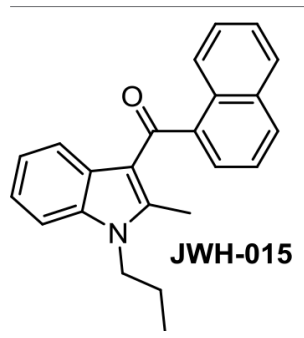

Reduces both tumor differentiated and cancer stem cell proliferation Reduces tumor growth and destabilizes the nuclear localization of $\beta$-catenin Colon cancer: HCT116 and SW48 cells

Colon cancer: DLD-1 cells

Breast cancer: MDA-MB-231

Colon cancer: DLD-1, CaCo-2, and SW620 cells

\section{Breast cancer: MDA-MB-231}

Lung cancer metastasis
In combination with oxaliplatin, blocks cancer proliferation (synergic effect)

Inhibits cancer growth via a CB1R lipid raft/caveolae-mediated mechanism

Inibits cancer growth, inducing mitotic catastrophe

\section{Increases invasiveness}

Inhibits metastasis
(Fiore et al., 2018)

(Proto et al., 2017)

(Gazzerro et al., 2010)

(Sarnataro et al., 2006)

(Santoro et al., 2009)

(Mohammadpour et al., 2017) (Marshall et al., 2011)
Renal carcinoma: 786-O, SMKT-R2, SMKT-R3, Caki-2, RCC-6, 769-P, Caki-1, and ACHN cells Myeloma: U266, U266-LR7, RPMI, RPMI-LR5, MM1.S, and MM1.R cells

Lung cancer and testicular cancer: A549 and

HoTu-10 cells

Prostate cancer: $\mathrm{NCaP}$ cells

Gastric cancer: SGC7901 and AGS cells

Hepatocellular carcinoma: BEL7402 cells Breast cancer: MDA-MB-231, MDA-MB-231 uc, and MDA-MB-468

\section{Breast cancer: $4 \mathrm{~T} 1$ and MCF-7 cells}

Non-small cell lung cancer (NSCLC): A549

cells
Tumor growth inhibition and GO/G1 cell cycle arrest via CB2R

activation

Proapoptotic effects

Proapoptotic effects

Prevents neuroendocrine differentiation

Inhibits cell migration and invasion through COX-2 downregulation

Induces cell cycle arrest and inhibits tumor proliferation and migration

Inhibits tumor growth and metastasis

Apoptosis and reduction of metastasis

Reduces tumor growth and inhibits macrophage recruitment
(Khan et al., 2018)

(Barbado et al., 2017)

(Müller et al., 2017)

(Morell et al., 2016)

(Xian et al., 2016)

(Xu et al., 2015)

(Qamri et al., 2009)

(Hanlon et al., 2016)

(Ravi et al., 2016) 


\section{Compound}

$\mathrm{OH}$

$\mathrm{C}^{\mathrm{O}}$

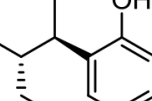

$\mathrm{OH}$

CP 55,940

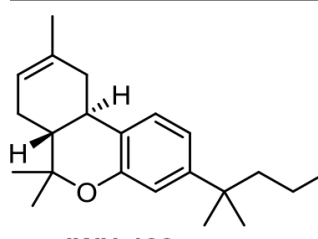

JWH-133
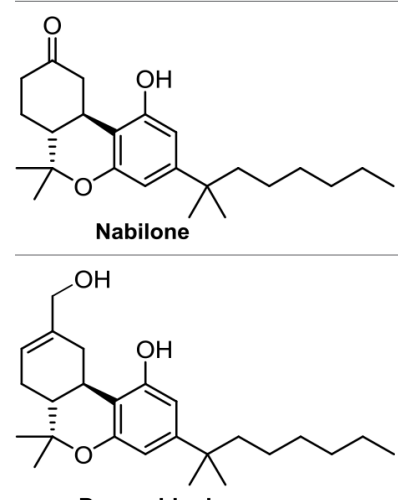

Brain cancer: human patients

Breast cancer: MDA-MB-231, MDA-MB-231

luc, and MDA-MB-468

Human cancer patients

Chemotherapy-induced nausea and vomiting

Velasco et al., 2016;

Badowski, 2017)
(Ortega et al., 2016)
Gastric cancer: human AGS adenocarcinoma

cells
Inhibits tumor growth and metastasis via CB2R

Apoptosis induction

(Qamri et al., 2009)
Dexanabinol in Patients With

Advanced Solid Tumours,

clinicaltrials.gov)

$$
\text { Dexanabinol }
$$

Leukemia, lymphoma, and colon cancer:
Jurkat, Raji, and HT-29 cells $\begin{aligned} & \text { Inhibition of DNA topoisomerase II and antiangiogenic effects } \\ & \text { et al., 2006; Kogan et al., 2007) }\end{aligned}$




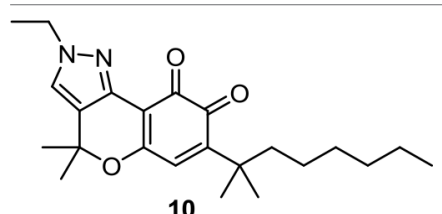

10<smiles>O=C1C(Cl)=C(N2CCOCC2)C(=O)c2c(O)ccc(O)c21</smiles>

Breast cancer: MCF-10A cells

Antiproliferative effects related with its GPR55 activity
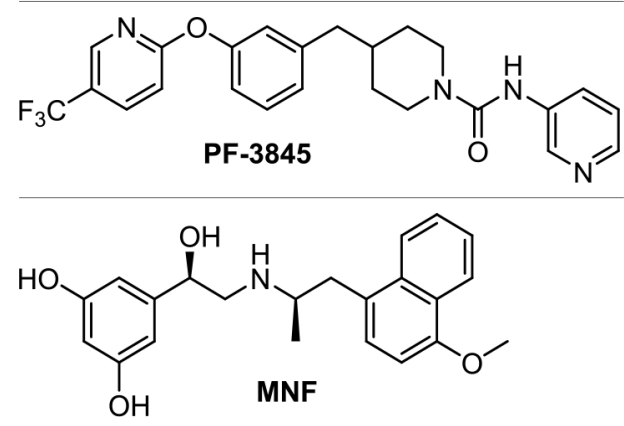

Hepatic and pancreatic cancers: HepG2 and

Impairs cancer cell motility via GPR55 signaling

(Paul et al., 2014)

Colon cancer: Colo-205 cells

Reduces viability, migration, and invasiveness through FAAH inhibition

(Wasilewski et al., 2017)

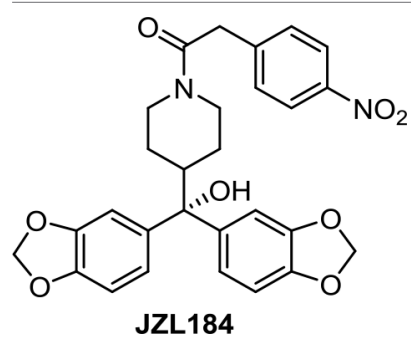

Colon cancer: HCT116, SW480, and LoVo

Regulates apoptosis and migration through MAGL inhibition

(Ma et al., 2016)

JZL184 


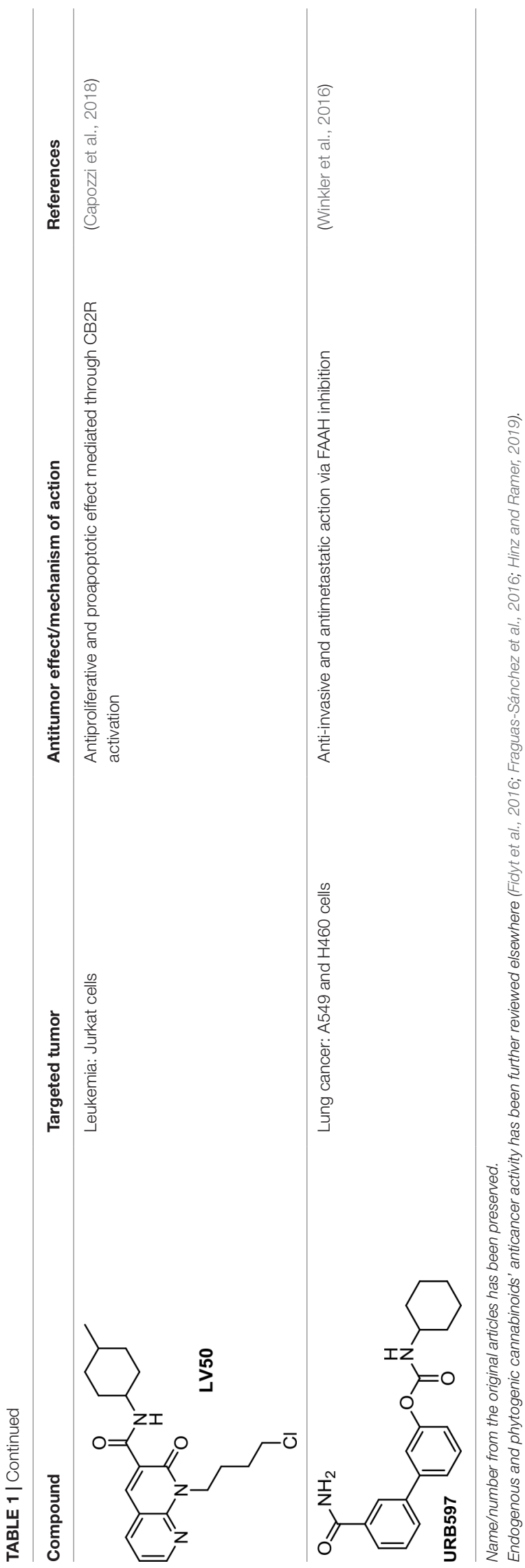

as the COX-2, 5-LOX, PPAR $\gamma$, mTOR, and p38 MAPK pathway (Hinz and Ramer, 2019).

The $\Delta^{9}$-THC plant precursor, $\Delta^{9}$-THCA, was shown to be slightly less active than its parent compound in human prostate carcinoma androgen receptor-negative and -positive cell lines (De Petrocellis et al., 2013), whereas in other cancer types such as breast, colon, gastric, glioma, and basophilic leukemia, they exert similar potency in vitro (Ligresti, 2006).

CBDA, the acidic precursor of $\mathrm{CBD}$, inhibits the migration of MDA-MB-231 cells through COX-2 (Takeda et al., 2017), while $\mathrm{CBC}$ and $\mathrm{CBG}$ are much less active than $\mathrm{CBD}$ or inactive in different cancer cell lines (De Petrocellis et al., 2013).

Quercetin, a flavonoid present in fruits and vegetables, inhibits the growth of human colon adenocarcinoma cells through CB1R (Refolo et al., 2015). Another flavonoid structurally closely related to quercetin, morin (Table 1), showed an apoptotic effect by a mechanism not fully resolved (Hyun et al., 2015), but interestingly, morin also showed analgesic effects mediated through CB2R (Jiang et al., 2017).

Terpenes present in Cannabis sativa such as myrcene, $\alpha$-pinene, and $\beta$-caryophyllene (BCP, Table 1) have been shown to exert synergic therapeutic actions with phytocannabinoids (Blasco-Benito et al., 2018). Anticancer and analgesic properties of $\beta$-caryophyllene have also been reported (Fidyt et al., 2016).

\section{Synthetic Cannabinoids}

Medicinal chemistry programs focused on cannabinoids led to the discovery of different scaffolds that constitute the synthetic cannabinoid family (Vemuri and Makriyannis, 2015). In particular, CP-55,940, WIN55,212-2, JWH-015, JWH-133, SR141716 (rimonabant), SR144528, and ACEA have been considered excellent pharmacological tools to provide insights into the endocannabinoid system. The cyclohexylphenol CP-55,940, initially developed by Pfizer, was radiolabeled in Allyn Howlett's laboratory (Yamada et al., 1996). Another CB1R/CB2R (cannabinoid receptor CB1/cannabinoid receptor CB2) mixed reference agonist is the aminoalkylindole WIN55,212-2 developed by Sterling Winthrop. From more than 400 cannabinoids synthesized in John W. Huffman's laboratory, JWH-015 became a reference THC derivative for showing better affinity for CB2R than for CB1R (Huffman and Marriott, 2008). Then, with the naphthoylindole derivative JWH-133, Huffman's team provided a potent selective CB2R receptor agonist versus $\mathrm{CB} 1 \mathrm{R}$.

\section{Arylpyrazoles}

Rimonabant (SR141716, Table 1), a CB1R inverse agonist, elicits alternative cell death pathways depending on the cell type affected. For example, Bifulco (Sarnataro et al., 2006) provides evidence for a lipid raft-mediated mechanism related to the CB1R in MDA-MB-231 cells, whereas it induces apoptosis in colon cancer through a CB1R-independent mechanism that involves the canonical $\mathrm{Wnt} / \beta$-catenin pathway and $\beta$-catenin target genes (Santoro et al., 2009; Proto et al., 2017; Fiore et al., 2018). Rimonabant induces cell cycle arrest and programmed cell death in leukemia cell lines 
by a mechanism unlikely to be CB1R-dependent due to a low expression of CB1R in the cell lines used (U937 and Jurkat cells) (Gallotta et al., 2010). Recently, rimonabant has been shown to reduce colon cancer stem cell proliferation, which may account for cancer initiation, progression, and metastasis (Fiore et al., 2018). Synergy with antineoplastic drugs has been explored. A synergic antitumor effect was observed when combining rimonabant and oxaliplatin in colon cancer (Gazzerro et al., 2010).

AM-251 (Table 1) is a CB1R antagonist structurally closely related to rimonabant. It often has been used as pharmacological tool. For instance, AM-251 allowed determining of the functional relevance of CB1R signaling in Hodgkin lymphoma (Benz et al., 2013) and in rhabdomyosarcoma (Marshall et al., 2011). As an antitumor agent, AM-251 has not been reported to have significant differences with rimonabant.

\section{Aminoalkylindoles}

WIN55,212-2, a CB1R/CB2R dual agonist, has been one of the most widely used pharmacological tools to get insights into the endocannabinoid system. WIN55,212-2 (Table 1) inhibits cell proliferation and migration in triple-negative breast cancer (Qamri et al., 2009); in prostate cancer (Morell et al., 2016); in gastric cancer (Xian et al., 2016); in hepatocellular carcinoma (Xu et al., 2015); in lung cancer, testicular cancer, and neuroblastoma (Müller et al., 2017); in myeloma (Barbado et al., 2017); and in renal carcinoma (Khan et al., 2018). Most of these results were confirmed in vivo in various mouse model systems. The contribution of WIN55,212-2 to the proliferation relies on a different mechanism of action also involving cooperation processes. CB2R is clearly involved in hepatocellular carcinoma (Xu et al., 2015), myeloma (Barbado et al., 2017), and renal carcinoma (Khan et al., 2018), whereas both $\mathrm{CB} 1 \mathrm{R}$ and $\mathrm{CB} 2 \mathrm{R}$ contribute to the antiproliferative activity in triple-negative breast cancer (Qamri et al., 2009). In the case of prostate cancer (LNCaP), WIN55,212-2 preserves the levels of $\mathrm{CB} 2 \mathrm{R}$ activity, which decrease during the neuroendocrine process (Morell et al., 2016). Cyclooxigenase-2 has been shown to be an important downstream target of WIN55,212-2 in gastric cancer metastasis (Xian et al., 2016). Moreover, this aminoalkylindole has been shown to improve inflammatory conditions, which ameliorate oncologic pathologies (Solbrig et al., 2010).

The naphthoylindole JWH-015 (Table 1) is characterized by high CB2R affinity, but it is not devoid of CB1R activity. CB2R activation has been reported to be involved in the antiproliferative effect of JWH-015 in different cancer cells, such as PC-3 prostate cancer cells (Olea-Herrero et al., 2009). In metastatic breast cancer MCF-7, crosstalk between CB2R and CXCR4 signaling seems to participate in the antiproliferative effect of JWH-015 (Nasser et al., 2011). In lung cancer cell lines, the effect of JWH015 is comparable to WIN55,212-2, with CB1R/CB2R agonistmediated antiproliferative effects (Preet et al., 2011). In cancer murine 4T1 and human MCF-7 mammary carcinoma cells, the action of JWH-015 seems to be complex, since it is not mediated either by CB1R or CB2R, or by GPR55, TRPV1, or TRPA1 receptors (Hanlon et al., 2016).

\section{Quinones}

Many quinones are cytotoxic through DNA intercalation, inhibition of DNA topoisomerase II enzyme, and free radical production. In this context, phytocannabinoids are interesting starting materials for preparing quinones. Thus, oxidation of CBD, $\Delta^{8}$-tetrahydrocannabinol, and cannabinol leads to para-quinone derivatives respectively named HU-331 (Table 1), HU-306, and HU-345 (Kogan et al., 2004). They all exert antiproliferative activity for Burkitt's lymphoma, T-cell lymphoma, glioblastoma, breast cancer, prostate cancer, lung cancer, and colon cancer. Efforts have been focused on the mechanism of action of HU-331, whose antitumor effect has been shown as not being directly mediated by CB1R or CB2R receptors (Kogan et al., 2006). HU-331 was found to specifically be an inhibitor of topoisomerase II, while having no effect on topoisomerase I (Kogan et al., 2007).

Based on the synthetic cannabinoid scaffold chromenopyrazole, para- and ortho-quinones were reported (Morales et al., 2013; Morales et al., 2015). As indicated by their profile, CB1R/ CB2R for para-quinones and CB2R for ortho-quinones, paraquinones (such as PM49, Table 1) inhibit prostate LNCaP cell viability through a mechanism involving oxidative stress, PPAR $\gamma$, and partially CB1R (Morales et al., 2013), while ortho-quinones (such as 10, Table 1) act on triple-negative breast cancer cells via CB2R activation and ROS production (Morales et al., 2015).

Recently, 1,4-naphthoquinone derivatives have been reported as efficient against triple-negative breast cancer (Badolato et al., 2019), which is not very surprising knowing that 1,4-naphthoquinone is a privilege scaffold for cytotoxicity. The cell viability assays assessed against the MDA-MB-231 cell line, which has been determined to overexpress GPR55 (Andradas et al., 2011), suggest that the most potent 1,4-naphthoquinone, 3a (Table 1), acts as an inverse agonist of GPR55.

\section{Naphthyridine and Naphthalene}

1,8-Naphthyridin-2-ones, CB2R agonists, have been shown to be, in general, more active against prostate carcinoma cells (DU-145 cell line) than MCF-7 breast carcinoma cells, gastric adenocarcinoma cells, and glioblastoma cells (Manera et al., 2012). Recently, the proapoptotic effect of the 2-oxo1,8-naphthyridine-3-carboxamide LV50 (Table 1) on Jurkat leukemia cells was reported to be mediated by $\mathrm{CB} 2 \mathrm{R}$ receptor (Capozzi et al., 2018).

Despite the expression of $\beta 2$-adrenoceptor in the HepG2 hepatocarcinoma cell line and its $\beta 2$-adrenergic properties, MNF [(R,R')-4'-methoxy-1-naphthylfenoterol, Table 1] causes growth arrest and apoptosis through signaling pathways downstream of GPR55 rather than a $\beta 2$-adrenergic-dependent mechanism (Paul et al., 2014).

\section{Others}

Apoptotic and necrotic cell death have been reported to be associated with elevated levels of AEA (Matas et al., 2007). Thus, inhibition of the enzymes involved in the biodegradation of the endocannabinoids has been shown to play a role in cancer 
cell viability, migration, and metastasis, as, for instance, does the FAAH inhibitor URB597 (Table 1) in lung cancer cells (Winkler et al., 2016). In colon cancer, FAAH inhibition (PF3845, Table 1) seems to be a better strategy than MAGL (JZL184, Table 1) or DAGL inhibition (RHC-80267) (Wasilewski et al., 2017). However, in other studies, JZL184 was shown to have antiproliferative activity in apoptotic LoVo, HCT116, and SW480 cells (Ma et al., 2016).

The 2-(3-hydroxycyclohexyl)phenol CP-55,940 (Table 1), a well-known CB1R/CB2R agonist, has been used as a pharmacological tool for comparing the antineoplastic activity induced by endogenous and synthetic cannabinoids on gastric cancer cells (Ortega et al., 2016). CP-55,940 and AEA induce similar apoptotic effects, whereas Meth-AEA is more effective at inducing necrosis through transient and rapid apoptosis.

The benzo[c]chromene JWH-133 (Table 1), structurally related to $\Delta^{8}$-THC, has been chosen for studying the mechanism of action of synthetic nonpsychotic cannabinoids on breast cancer growth and metastasis due to its selectivity for CB2R (Qamri et al., 2009).

Interestingly, dexanabinol and nabilone (Table 1), synthetic analogues of THC, are the two synthetic molecules that have further progressed in the clinic. While nabilone is approved in certain countries for the treatment of chemotherapy-induced nausea and vomiting (Ware et al., 2008; Velasco et al., 2016; Badowski, 2017), dexanabinol is currently in clinical trials for the management of brain cancer (A Phase 1 Study of Dexanabinol in Patients With Advanced Solid Tumours, ClinicalTrials.gov; Dexanabinol in Patients With Brain Cancer, ClinicalTrials.gov). It is interesting to highlight that dexanabinol acts as an NMDA (N-methyl-D-aspartate) receptor antagonist and an inhibitor of the activity of nuclear factor kappa B (NF-kB) not binding CB1R and CB2R. Therefore, its antitumor molecular mechanisms could be mediated through the aforementioned targets (Striem et al., 1997; Jüttler et al., 2004).

Moreover, CB2R agonists have been the focus of molecular targets associated with photodynamic therapy (PDT) agents for developing target-specific PDT photosensitizers. In this sense, IR700DX-mbc94, a conjugate between a phthalocyanine dye and the CB2R inverse agonist SR144528, showed significant activity in the malignant astrocytoma cell line (Zhang et al., 2014). Another strategy is the co-administration of CB2R agonist and a PDT photosensitizer; synergic effects between the PDT agent IR700DX-6 T and JWH-133 have been observed in triplenegative breast cancer tumors (Zhang et al., 2018a).

Considering that GPR55 promotes cancer cell proliferation, peptide binders of GPR55 have been prepared and studied to inhibit the proliferation of EHEB and DeFew cells, two GPR55positive B-lymphoblastoid cell lines (Mangini et al., 2017). These peptide binders are used as substitute tools for an antibody-based therapy strategy, since there is a lack of humanized monoclonal antibodies for this receptor.

\section{IN SILICO ADMET PROFILE}

Besides theiractivityand antiproliferative profile, pharmacokinetic aspects should be considered in selecting cannabinoid scaffolds for further development towards the oncology scenario. In this context, we have estimated the drug-likeness of the previously listed molecules.

ADMET properties were predicted using QikProp, integrated in the Maestro software (Schrödinger, LLC, New York, 2019) and the admetSAR web server (Cheng et al., 2012; Dong et al., 2018; Yang et al., 2018). Selected parameters are shown in Table 2. These calculations provide a common parameterization of physicochemical descriptors that allows comparison of ADMET profiles, which is a useful criterion for chemical probe selection for further development.

According to our in silico calculations, most of the cannabinoids analyzed herein follow the Lipinski and Jorgensen pharmacokinetic rules (Lipinski, 2001; Jorgensen and Duffy, 2002). It is interesting to underline that our results are consistent with the experimental ADMET parameters published for some of these cannabinoids (Grotenhermen, 2003; Stout and Cimino, 2014; Zendulka et al., 2016). As shown in Table 2, the prediction of human oral absorption, blood-brain barrier permeability, bioavailability, human intestinal permeability, or binding to human serum albumin suggests that these cannabinoids have an appropriate drug profile. However, solubility as well as metabolic and toxicity parameters of specific compounds such as JZL184, LV50, JWH-015, or 3a fall outside the range predicted for FDAapproved small-molecule drugs (Hansen et al., 2009; Zhu et al., 2009; Xu et al., 2012; Li et al., 2014). Certain cannabinoids of phytogenic and synthetic nature may inhibit the activity of one or more cytochrome P450 isoforms (Table 2). Since these enzymes are involved in over $70 \%$ of human drug metabolism (Guengerich, 2008), their interactions with cannabinoids can affect drug clearance, consequently enhancing toxicity. This should be especially taken into account when combining these cannabinoids with other chemotherapy agents. Consequently, when moving forward toward the clinic, selected cannabinoids could be discarded for pharmacokinetic issues.

\section{PERSPECTIVE}

The first report on the antitumor activity of phytocannabinoids was published over four decades ago (Munson et al., 1975). Nevertheless, it is only in recent years that interest in these properties has grown. In addition to the well-established palliative effects of cannabinoids in cancer therapy, cannabinoids have attracted attention as possible anticancer drugs. There is a growing body of evidence showing that endogenous, phytogenic, and synthetic cannabinoids, and modulators of endocannabinoid biosynthesis, inhibit proliferation of a wide spectrum of tumor cells. In this report, we aim to provide a perspective of the current drug development scenario of cannabinoid-based antitumor strategies and their potential pathway to the clinic.

Endogenous cannabinoids and their synthetic derivatives have widely exhibited their ability to modulate cell proliferation, angiogenesis, and metastasis in a number of cancer cell types. However, concerning their possible exogenous application 
TABLE 2 | Physicochemical descriptors of selected compounds as calculated using QikProp (integrated in Maestro, Schrödinger, LLC, New York, 2019) and the admetSAR web server (Cheng et al., 2012; Dong et al., 2018; Yang et al., 2018).

\begin{tabular}{|c|c|c|c|c|c|c|c|c|c|c|c|c|c|}
\hline \multirow[t]{2}{*}{ Compd } & \multirow[t]{2}{*}{ QPlogSa } & \multirow[t]{2}{*}{ QlogBB $^{b}$} & \multirow[t]{2}{*}{ QPlogKhsa $^{c}$} & \multirow[t]{2}{*}{ QPPCacod $^{d}$} & \multirow{2}{*}{$\begin{array}{c}\% \\
\text { Abs. }\end{array}$} & \multirow{2}{*}{$\begin{array}{c}\text { hERG } \\
\text { Blockage }\end{array}$} & \multirow{2}{*}{$\begin{array}{c}\text { AMES } \\
\text { Toxicityg }\end{array}$} & \multirow[t]{2}{*}{ Carcinogenicityh } & \multirow{2}{*}{$\begin{array}{l}\text { Acute } \\
\text { oral } \\
\text { toxicityi }\end{array}$} & \multirow[t]{2}{*}{$\mathbf{L D}_{50}{ }^{\mathrm{j}}$} & \multicolumn{3}{|c|}{ CYP substrate/inhibition ${ }^{k}$} \\
\hline & & & & & & & & & & & CYP3A4 & CYP2C9 & CYP2D6 \\
\hline AEA & -6.20 & -1.56 & 0.58 & 890 & 100 & weak inhibitor & non-toxic & non-carcinogenic & III & 1.52 & $\begin{array}{l}\text { substrate/ } \\
\text { non-inhibitor }\end{array}$ & $\begin{array}{c}\text { non-substrate/ } \\
\text { non-inhibitor }\end{array}$ & $\begin{array}{l}\text { substrate/ } \\
\text { non-inhibitor }\end{array}$ \\
\hline Met-AEA & -5.02 & -1.09 & 0.47 & 2,268 & 100 & weak inhibitor & non-toxic & non-carcinogenic & III & 1.65 & $\begin{array}{l}\text { substrate/ } \\
\text { non-inhibitor }\end{array}$ & $\begin{array}{c}\text { non-substrate/ } \\
\text { non-inhibitor }\end{array}$ & $\begin{array}{l}\text { substrate/ } \\
\text { non-inhibitor }\end{array}$ \\
\hline ACEA & -4.72 & -0.44 & 0.75 & 3,486 & 100 & weak inhibitor & non-toxic & non-carcinogenic & III & 2.24 & $\begin{array}{l}\text { substrate/ } \\
\text { non-inhibitor }\end{array}$ & $\begin{array}{c}\text { non-substrate/ } \\
\text { non-inhibitor }\end{array}$ & $\begin{array}{l}\text { substrate/ } \\
\text { non-inhibitor }\end{array}$ \\
\hline $4 \mathrm{~g}$ & -6.18 & -1.39 & 0.60 & 1,097 & 100 & weak inhibitor & non-toxic & non-carcinogenic & III & 1.99 & $\begin{array}{l}\text { substrate/ } \\
\text { non-inhibitor }\end{array}$ & $\begin{array}{c}\text { non-substrate/ } \\
\text { non-inhibitor }\end{array}$ & $\begin{array}{c}\text { substrate/ } \\
\text { non-inhibitor }\end{array}$ \\
\hline $5 c$ & -5.18 & -0.96 & 0.22 & 2,443 & 100 & weak inhibitor & non-toxic & non-carcinogenic & III & 1.43 & $\begin{array}{l}\text { substrate/ } \\
\text { non-inhibitor }\end{array}$ & $\begin{array}{c}\text { non-substrate/ } \\
\text { non-inhibitor }\end{array}$ & $\begin{array}{l}\text { substrate/ } \\
\text { non-inhibitor }\end{array}$ \\
\hline THC & -6.64 & -0.10 & 1.24 & 4,475 & 100 & weak inhibitor & non-toxic & non-carcinogenic & III & 2.59 & $\begin{array}{l}\text { substrate/ } \\
\text { non-inhibitor }\end{array}$ & $\begin{array}{l}\text { substrate/ } \\
\text { inhibitor }\end{array}$ & $\begin{array}{c}\text { non-substrate/ } \\
\text { non-inhibitor }\end{array}$ \\
\hline CBD & -6.11 & -0.49 & 1.06 & 2,437 & 100 & weak inhibitor & non-toxic & non-carcinogenic & III & 2.50 & $\begin{array}{l}\text { substrate/ } \\
\text { inhibitor }\end{array}$ & $\begin{array}{l}\text { substrate/ } \\
\text { inhibitor }\end{array}$ & $\begin{array}{c}\text { non-substrate/ } \\
\text { non-inhibitor }\end{array}$ \\
\hline CBG & -6.19 & -0.84 & 1.08 & 2,045 & 100 & weak inhibitor & non-toxic & non-carcinogenic & III & 2.29 & $\begin{array}{l}\text { substrate/ } \\
\text { inhibitor }\end{array}$ & $\begin{array}{c}\text { non-substrate/ } \\
\text { inhibitor }\end{array}$ & $\begin{array}{c}\text { non-substrate/ } \\
\text { non-inhibitor }\end{array}$ \\
\hline СвC & -7.13 & -0.42 & 1.29 & 3,569 & 100 & weak inhibitor & non-toxic & non-carcinogenic & III & 2.55 & $\begin{array}{c}\text { substrate/ } \\
\text { non-inhibitor }\end{array}$ & $\begin{array}{c}\text { non-substrate/ } \\
\text { non-inhibitor }\end{array}$ & $\begin{array}{c}\text { non-substrate/ } \\
\text { non-inhibitor }\end{array}$ \\
\hline Quercetin & -2.89 & -2.41 & -0.34 & 18 & 52 & weak inhibitor & non-toxic & non-carcinogenic & $\|$ & 3.02 & $\begin{array}{l}\text { non-substrate/ } \\
\text { inhibitor }\end{array}$ & $\begin{array}{c}\text { non-substrate/ } \\
\text { non-inhibitor }\end{array}$ & $\begin{array}{c}\text { non-substrate/ } \\
\text { non-inhibitor }\end{array}$ \\
\hline Morin & -2.85 & -2.34 & -0.35 & 20 & 53 & weak inhibitor & non-toxic & non-carcinogenic & $\|$ & 3.08 & $\begin{array}{l}\text { non-substrate/ } \\
\text { inhibitor }\end{array}$ & $\begin{array}{c}\text { non-substrate/ } \\
\text { non-inhibitor }\end{array}$ & $\begin{array}{c}\text { non-substrate/ } \\
\text { non-inhibitor }\end{array}$ \\
\hline BCP & -6.22 & 1.04 & 0.96 & 9,906 & 100 & weak inhibitor & non-toxic & non-carcinogenic & III & 1.43 & $\begin{array}{c}\text { substrate/ } \\
\text { non-inhibitor }\end{array}$ & $\begin{array}{c}\text { non-substrate/ } \\
\text { non-inhibitor }\end{array}$ & $\begin{array}{c}\text { non-substrate/ } \\
\text { non-inhibitor }\end{array}$ \\
\hline SR141716 & -8.78 & 0.44 & 1.22 & 3,812 & 100 & weak inhibitor & non-toxic & non-carcinogenic & III & 2.54 & $\begin{array}{l}\text { substrate/ } \\
\text { non-inhibitor }\end{array}$ & $\begin{array}{c}\text { non-substrate/ } \\
\text { inhibitor }\end{array}$ & $\begin{array}{c}\text { non-substrate/ } \\
\text { inhibitor }\end{array}$ \\
\hline AM-251 & -9.02 & 0.47 & 1.27 & 3,812 & 100 & weak inhibitor & non-toxic & non-carcinogenic & III & 2.54 & $\begin{array}{l}\text { substrate/ } \\
\text { non-inhibitor }\end{array}$ & $\begin{array}{c}\text { non-substrate/ } \\
\text { inhibitor }\end{array}$ & $\begin{array}{c}\text { non-substrate/ } \\
\text { inhibitor }\end{array}$ \\
\hline WIN55,212-2 & -6.26 & 0.01 & 1.03 & 4,869 & 100 & strong inhibitor & non-toxic & non-carcinogenic & III & 2.47 & $\begin{array}{l}\text { substrate/ } \\
\text { inhibitor }\end{array}$ & $\begin{array}{c}\text { non-substrate/ } \\
\text { non-inhibitor }\end{array}$ & $\begin{array}{l}\text { substrate/ } \\
\text { non-inhibitor }\end{array}$ \\
\hline JWH-015 & -6.04 & 0.02 & 1.10 & 4,893 & 100 & weak inhibitor & toxic & non-carcinogenic & III & 2.52 & $\begin{array}{l}\text { substrate/ } \\
\text { non-inhibitor }\end{array}$ & $\begin{array}{c}\text { non-substrate/ } \\
\text { non-inhibitor }\end{array}$ & $\begin{array}{l}\text { substrate/ } \\
\text { non-inhibitor }\end{array}$ \\
\hline CP-55,940 & -6.49 & -1.78 & 0.89 & 399 & 100 & weak inhibitor & non-toxic & non-carcinogenic & III & 2.08 & $\begin{array}{l}\text { substrate/ } \\
\text { inhibitor }\end{array}$ & $\begin{array}{c}\text { non-substrate/ } \\
\text { non-inhibitor }\end{array}$ & $\begin{array}{c}\text { non-substrate/ } \\
\text { non-inhibitor }\end{array}$ \\
\hline JWH-133 & -9.22 & 0.94 & 1.65 & 9,906 & 100 & weak inhibitor & non-toxic & non-carcinogenic & III & 2.13 & $\begin{array}{l}\text { substrate/ } \\
\text { non-inhibitor }\end{array}$ & $\begin{array}{c}\text { non-substrate/ } \\
\text { non-inhibitor }\end{array}$ & $\begin{array}{c}\text { non-substrate/ } \\
\text { non-inhibitor }\end{array}$ \\
\hline Nabilone & -7.08 & -0.81 & 1.24 & 1,348 & 100 & weak inhibitor & non-toxic & non-carcinogenic & III & 2.54 & $\begin{array}{l}\text { substrate/ } \\
\text { non-inhibitor }\end{array}$ & $\begin{array}{c}\text { substrate/ } \\
\text { inhibitor }\end{array}$ & $\begin{array}{c}\text { non-substrate/ } \\
\text { non-inhibitor }\end{array}$ \\
\hline Dexanabinol & -7.25 & -0.93 & 1.28 & 1,430 & 100 & weak inhibitor & non-toxic & non-carcinogenic & III & 2.51 & $\begin{array}{l}\text { substrate/ } \\
\text { non-inhibitor }\end{array}$ & $\begin{array}{c}\text { non-substrate/ } \\
\text { non-inhibitor }\end{array}$ & $\begin{array}{c}\text { non-substrate/ } \\
\text { non-inhibitor }\end{array}$ \\
\hline
\end{tabular}


TABLE 2 | Continued

\begin{tabular}{|c|c|c|c|c|c|c|c|c|c|c|c|c|c|}
\hline \multirow[t]{2}{*}{ Compd } & \multirow[t]{2}{*}{ QPlogSa } & \multirow[t]{2}{*}{ QlogBB $^{b}$} & \multirow[t]{2}{*}{ QPlogKhsa $^{c}$} & \multirow[t]{2}{*}{ QPPCaco $^{d}$} & \multirow{2}{*}{$\begin{array}{c}\% \\
\text { Abs. }\end{array}$} & \multirow{2}{*}{$\begin{array}{c}\text { hERG } \\
\text { Blockage }^{f}\end{array}$} & \multirow{2}{*}{$\begin{array}{l}\text { AMES } \\
\text { Toxicity }\end{array}$} & \multirow[t]{2}{*}{ Carcinogenicity ${ }^{h}$} & \multirow{2}{*}{$\begin{array}{l}\text { Acute } \\
\text { oral } \\
\text { toxicityi }\end{array}$} & \multirow[t]{2}{*}{$\mathbf{L D}_{50}{ }^{\mathrm{j}}$} & \multicolumn{3}{|c|}{ CYP substrate/inhibitionk } \\
\hline & & & & & & & & & & & CYP3A4 & CYP2C9 & CYP2D6 \\
\hline HU-331 & -5.35 & -0.62 & 0.65 & 1,536 & 100 & weak inhibitor & non-toxic & non-carcinogenic & III & 2.34 & $\begin{array}{c}\text { substrate/ } \\
\text { non-inhibitor }\end{array}$ & $\begin{array}{c}\text { non-substrate/ } \\
\text { non-inhibitor }\end{array}$ & $\begin{array}{c}\text { non-substrate/ } \\
\text { non-inhibitor }\end{array}$ \\
\hline PM49 & -5.46 & -1.19 & 0.45 & 507 & 96 & weak inhibitor & non-toxic & non-carcinogenic & III & 2.54 & $\begin{array}{c}\text { substrate/ } \\
\text { non-inhibitor }\end{array}$ & $\begin{array}{c}\text { non-substrate/ } \\
\text { non-inhibitor }\end{array}$ & $\begin{array}{c}\text { non-substrate/ } \\
\text { non-inhibitor }\end{array}$ \\
\hline 10 & -6.27 & -0.78 & 0.59 & 1,599 & 100 & weak inhibitor & non-toxic & non-carcinogenic & III & 2.65 & $\begin{array}{c}\text { substrate/ } \\
\text { non-inhibitor }\end{array}$ & $\begin{array}{c}\text { non-substrate/ } \\
\text { non-inhibitor }\end{array}$ & $\begin{array}{c}\text { non-substrate/ } \\
\text { non-inhibitor }\end{array}$ \\
\hline 3a & -1.96 & -0.71 & -0.66 & 342 & 78 & strong inhibitor & non-toxic & non-carcinogenic & III & 2.55 & $\begin{array}{l}\text { substrate/ } \\
\text { non-inhibitor }\end{array}$ & $\begin{array}{c}\text { non-substrate/ } \\
\text { non-inhibitor }\end{array}$ & $\begin{array}{c}\text { non-substrate/ } \\
\text { non-inhibitor }\end{array}$ \\
\hline PF-3845 & -7.26 & -0.41 & 0.81 & 976 & 100 & weak inhibitor & non-toxic & non-carcinogenic & III & 2.83 & $\begin{array}{l}\text { substrate/ } \\
\text { inhibitor }\end{array}$ & $\begin{array}{l}\text { non-substrate/ } \\
\text { inhibitor }\end{array}$ & $\begin{array}{c}\text { non-substrate/ } \\
\text { non-inhibitor }\end{array}$ \\
\hline MNF & -3.49 & -1.21 & 0.20 & 91 & 79 & weak inhibitor & non-toxic & non-carcinogenic & III & 2.42 & $\begin{array}{c}\text { substrate/ } \\
\text { non-inhibitor }\end{array}$ & $\begin{array}{c}\text { non-substrate/ } \\
\text { non-inhibitor }\end{array}$ & $\begin{array}{c}\text { non-substrate/ } \\
\text { inhibitor }\end{array}$ \\
\hline JZL184 & -4.99 & -1.40 & 0.30 & 217 & 77 & weak inhibitor & toxic & non-carcinogenic & III & 2.68 & $\begin{array}{c}\text { substrate/ } \\
\text { inhibitor }\end{array}$ & $\begin{array}{c}\text { non-substrate/ } \\
\text { non-inhibitor }\end{array}$ & $\begin{array}{c}\text { non-substrate/ } \\
\text { non-inhibitor }\end{array}$ \\
\hline LV50 & -6.41 & -0.43 & 0.56 & 1,706 & 100 & weak inhibitor & toxic & non-carcinogenic & $\|$ & 2.65 & $\begin{array}{c}\text { substrate/ } \\
\text { inhibitor }\end{array}$ & $\begin{array}{c}\text { non-substrate/ } \\
\text { non-inhibitor }\end{array}$ & $\begin{array}{c}\text { non-substrate/ } \\
\text { non-inhibitor }\end{array}$ \\
\hline URB597 & -5.35 & -1.31 & 0.34 & 321 & 89 & weak inhibitor & non-toxic & non-carcinogenic & III & 2.15 & $\begin{array}{c}\text { non-substrate/ } \\
\text { non-inhibitor }\end{array}$ & $\begin{array}{c}\text { non-substrate/ } \\
\text { non-inhibitor }\end{array}$ & $\begin{array}{c}\text { non-substrate/ } \\
\text { non-inhibitor }\end{array}$ \\
\hline
\end{tabular}

Physicochemical descriptors calculated by QikProp: aPredicted aqueous solubility [-6.5/0.5]. ${ }^{b}$ Predicted log of the brain/blood partition coefficient [-3.0/1.2] cPrediction of binding to human serum albumin (-1.5-1.5). dApparent Caco-2 cell permeability [ $\left[\mathrm{nm} \mathrm{s}^{-1}\right.$, intestinal drug permeability, < 25 poor, > 500 excellent]. QikProp predictions are for non-active transport; eHuman oral absorption in the Gl [< 25\% is poor]; [range of $95 \%$ of drugs].

Toxicity parameters calculated with the admetSAR prediction tool: fPredicted hERG blockade: compounds are classified according to the previously published approach as strong inhibitors (II ${ }_{50}<1 \mu M$ ) or "non-blockers" exhibiting

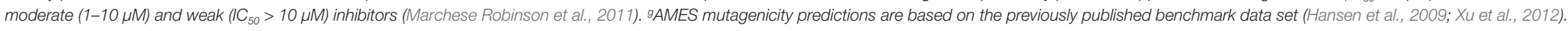

"Carcinogenic potency is divided into three classes, labeled as "danger," "warning," and "non-required," according to the $T D_{50}$ (median toxic dose) values. Carcinogenic compounds with $T D_{50} \leq 10 \mathrm{mg} / \mathrm{kg}$ body wt/day were assigned as "danger," those with $T D_{50}>10 \mathrm{mg} / \mathrm{kg}$ body wt/day were assigned as "warning," and non-carcinogenic chemicals were assigned as "non-required" (Lagunin et al., 2009; Li et al., 2015).

"Compounds are classified into four categories based on the criterion of the US EPA (Category I contains compounds with $L D_{50}$ values less than or equal to $50 \mathrm{mg} / \mathrm{kg}$; Category II contains compounds with $L D_{50}$ values greater than 50 $\mathrm{mg} / \mathrm{kg}$ but less than $500 \mathrm{mg} / \mathrm{kg}$; Category III includes compounds with $L D_{50}$ values greater than $500 \mathrm{mg} / \mathrm{kg}$ but less than $5000 \mathrm{mg} / \mathrm{kg}$; Category IV consists of compounds with $L D_{50}$ values greater than $5000 \mathrm{mg} / \mathrm{kg}$ ) (Li et al., 2014). iPredicted median lethal dose $\left(L D_{50}\right)$ in rat model (acute toxicity in mol/kg) (Zhu et al., 2009).

kMetabolism parameters from admetSAR: Molecules were classified as substrate or non-substrate, and inhibitor or non-inhibitor of the different CYP450 isoforms, according to the previously published classification (Carbon-Mangels and Hutter, 2011; Cheng et al., 2011a, Cheng et al., 2011b). 
for cancer treatment, their lipid nature along with possible alterations of the metabolism of the endocannabinoid system may decrease the pharmaceutical interest for this family. In fact, eicosanoid degradation can trigger handling difficulties as well as chemical stability issues.

On the other hand, phytocannabinoids and their synthetic analogues are further moving toward the bedside as potential antitumor agents. The natural occurring scaffold has been the most explored for their antiproliferative potential. As previously summarized, compounds isolated from Cannabis such as THC or CBD can reduce tumor growth in vitro and in vivo through different mechanisms depending on the cancer type. Remarkably, pilot studies and early-phase clinical trials indicate positive results regarding the survival of glioblastoma patients upon treatment with combinations of the aforementioned phytocannabinoids (A Pilot Study of Dronabinol for Adult Patients With Primary Gliomas, ClinicalTrials.gov; TN-TC11G (THC+CBD) Combination With Temozolomide and Radiotherapy in Patients With Newly-Diagnosed Glioblastoma, ClinicalTrials. gov; Guzmán et al., 2006).

Besides its promising anticancer potential, the pharmacokinetics of $\mathrm{CBD}$ should be taken carefully in the oncological field. This compound can inhibit the cytochrome isoform CYP3A4 (Zendulka et al., 2016), which may alter the metabolism of other drugs when used in combination. This is especially relevant due to the current use of drug cocktails for cancer treatment.

In line with these findings, it is interesting to underline the promising cannabis entourage effect. Synergic antitumor responses have been observed upon cancer treatment with cannabis botanical preparations (Blasco-Benito et al., 2018), exhibiting better results than pure phytocannabinoids administrated separately. Therefore, cannabinoid combinations may provide an improved antiproliferative strategy for cancer management.

Due to intellectual property pharmaceutical aspects, synthetic derivatives of phytogenic cannabinoids such as dexanabinol are also at advanced preclinical stages for the potential treatment of solid tumors (A Phase 1 Study of Dexanabinol in Patients With Advanced Solid Tumours, ClinicalTrials.gov; Dexanabinol in Patients With Brain Cancer," ClinicalTrials.gov).

Moreover, the cannabinoid-quinones analyzed herein also represent a promising chemotype for anticancer research. In addition to their multitarget antitumor actions, they present a suitable pharmacokinetic profile, being, in our opinion, a good drug-like prototype for further development. As commented, the putative cannabinoid receptor GPR55 is considered an emerging target in cancer therapy (Andradas et al., 2011). Thus, GPR55 antagonists should be explored as antitumor drugs. Moreover, due to the overexpression of this receptor in specific tumors, compounds that specifically bind GPR55 might represent valuable tools as tumor-targeting agents for delivery of classical chemotherapeutic drugs. In this regard, the previously mentioned 1,4-naphthoquinones, such as 3a, or naphthylfenoterols, such as MNF, could be interesting candidates for the pursuit of this cannabinoid anticancer approach.
Arylpyrazoles, aminoalkylindoles, and other cannabinoid derivatives such as napththyridine need additional antiproliferative in vitro and in vivo assays to be considered for further antitumor drug discovery stages. Endocannabinoid enzyme inhibitors such as URB597 and JZL184 should also be further explored since they may provide complementary anticancer strategies.

A major concern when considering new molecules as antitumor agents is their selectivity for cancer cells versus normal cells. Interestingly, phytocannabinoids such as $\Delta^{9}$-THC (Caffarel et al., 2006; Caffarel et al., 2008) and cannabinoid-quinones such as PM49 and 10 (Morales et al., 2013; Morales et al., 2015) have shown selective toxicity toward cancer cells versus their nontransformed counterparts. This should be taken into account when selecting suitable entities for further development.

The role of the endocannabinoid system in carcinogenesis is not fully unraveled. Therefore, it is difficult to choose a specific cannabinoid chemotype for optimal anticancer drug development. Nowadays, major hopes are coming from phytocannabinoids and their synthetic derivatives since they are steps forward in the clinic race. However, parallel systematic exploration of promising scaffolds presenting optimized ADMET profiles along with diverse mechanistic antiproliferative effects will probably provide wider antitumor spectra.

In this perspective, we have been reporting cannabinoid-based scaffolds as single anticancer agents. However, over the last years, new anticancer strategies toward clinical translation of cannabinoids have been explored. Combinational therapy involving synergies between cannabinoids and other anticancer agents is one of these approaches (Gazzerro et al., 2010; Torres et al., 2011; Scott et al., 2017; LópezValero et al., 2018; Zhang et al., 2018a). Such combined therapies allow targeting of tumor progression at different levels. Another strategy will be the use of cannabinoids in preventive conditions (Liu et al., 2010; Khan et al., 2018). Since inflammation is a common risk factor for cancer, and some cannabinoids have shown antiinflammatory properties, they could play a role in chemoprevention.

\section{DATA AVAILABILITY STATEMENT}

All datasets generated for this study are included in the manuscript and/or the supplementary files.

\section{AUTHOR CONTRIBUTIONS}

The authors equally contributed to this manuscript.

\section{FUNDING}

N.J. thanks the Spanish Ministry for its support through MINECO/ FEDER SAF2015-68580-C2-2-R and RTI2018-095544-B-100. P.M. is grateful to the CAM program "Atracción de Talento," number 2018-T2BMD-10819. We acknowledge support of the publication fee by the CSIC Open Access Publication Support Initiative through its Unit of Information Resources for Research (URICI). 


\section{REFERENCES}

A phase 1 study of dexanabinol in patients with advanced solid tumours, ClinicalTrials.gov. Available at: https://clinicaltrials.gov/ct2/show/NCT014 89826?term=Dexanabinol\&rank=3 (Accessed February 27, 2019).

A pilot study of dronabinol for adult patients with primary gliomas, ClinicalTrials. gov, Available at: https://clinicaltrials.gov/ct2/show/results/NCT00314808? term $=$ cannabinoids\&cond $=$ Cancer $\&$ draw $=3 \&$ rank $=15$ (Accessed February $28,2019)$.

Andradas, C., Caffarel, M. M., Pérez-Gómez, E., Salazar, M., Lorente, M., Velasco, G., et al. (2011). The orphan G protein-coupled receptor GPR55 promotes cancer cell proliferation via ERK. Oncogene 30, 245-252. doi: 10.1038/onc.2010.402

Badolato, M., Carullo, G., Caroleo, M. C., Cione, E., Aiello, F., and Manetti, F. (2019). Discovery of 1,4-naphthoquinones as a new class of antiproliferative agents targeting GPR55. ACS Med. Chem. Lett., 10 (4), 402-406. doi: 10.1021/ acsmedchemlett.8b00333

Badowski, M. E. (2017). A review of oral cannabinoids and medical marijuana for the treatment of chemotherapy-induced nausea and vomiting: a focus on pharmacokinetic variability and pharmacodynamics. Cancer Chemother. Pharmacol. 80 (3), 441-449. doi: 10.1007/s00280-017-3387-5

Barbado, M. V., Medrano, M., Caballero-Velázquez, T., Álvarez-Laderas, I., Sánchez-Abarca, L. I., García-Guerrero, E., et al. (2017). Cannabinoid derivatives exert a potent anti-myeloma activity both in vitro and in vivo. Int. J. Cancer 140, 674-685. doi: 10.1002/ijc.30483

Benz, A. H., Renné, C., Maronde, E., Koch, M., Grabiec, U., Kallendrusch, S., et al. (2013). Expression and functional relevance of cannabinoid receptor 1 in Hodgkin lymphoma. PLoS One 8e e81675. doi: 10.1371/journal.pone.0081675

Blasco-Benito, S., Seijo-Vila, M., Caro-Villalobos, M., Tundidor, I., Andradas, C., García-Taboada, E., et al. (2018). Appraising the "entourage effect" antitumor action of a pure cannabinoid versus a botanical drug preparation in preclinical models of breast cancer. Biochem. Pharmacol. 157, 285-293. doi: 10.1016/j.bcp.2018.06.025

Blázquez, C., Carracedo, A., Barrado, L., Real, P. J., Fernández-Luna, J. L., Velasco, G., et al. (2006). Cannabinoid receptors as novel targets for the treatment of melanoma. FASEB J. 20 (14), 2633-2635.

Caffarel, M. M., Morelno-Bueno, G., Cerutti, C., Palacios, J., Guzman, M., Mechta-Grigoriou, F., et al. (2008). JunD is involved in the antiproliferative effect of Delta9-tetrahydrocannabinol on human breast cancer cells. Oncogene 27, 5033-5044. doi: 10.1038/onc.2008.145

Caffarel, M. M., Sarrió, D., Palacios, J., Guzmán, M., and Sánchez, C. (2006). Delta9-tetrahydrocannabinol inhibits cell cycle progression in human breast cancer cells through Cdc2 regulation. Cancer Res. 66, 6615-6621. doi: 10.1158/ 0008-5472.CAN-05-4566

Capozzi, A., Mattei, V., Martellucci, S., Manganelli, V., Saccomanni, G., Garofalo, T., et al. (2018). Anti-proliferative properties and proapoptotic function of new CB2 selective cannabinoid receptor agonist in Jurkat leukemia cells. Int. J. Mol. Sci. 19, 1-20. doi: 10.3390/ijms19071958

Carbon-Mangels, M., and Hutter, M. C. (2011). Selecting relevant descriptors for classification by Bayesian estimates: a comparison with decision trees and support vector machines approaches for disparate data sets. Mol. Inform. 30, 885-895. doi: 10.1002/minf.201100069

Chakravarti, B., Ravi, J., and Ganju, R. K. (2014). Cannabinoids as therapeutic agents in cancer: current status and future implications. Oncotarget 5, 58525872. Available at: http://www.ncbi.nlm.nih.gov/pubmed/25115386. doi: 10.18632/oncotarget.2233

Cheng, F., Li, W., Zhou, Y., Shen, J., Wu, Z., Liu, G., et al. (2012). admetSAR: a comprehensive source and free tool for assessment of chemical ADMET properties. J. Chem. Inf. Model. 52, 3099-3105. doi: 10.1021/ci300367a

Cheng, F., Yu, Y., Shen, J., Yang, L., Li, W., Liu, G., et al. (2011a). Classification of cytochrome $\mathrm{P} 450$ inhibitors and noninhibitors using combined classifiers. J. Chem. Inf. Model. 51, 996-1011. doi: 10.1021/ci200028n

Cheng, F., Yu, Y., Zhou, Y., Shen, Z., Xiao, W., Liu, G., et al. (2011b). Insights into molecular basis of cytochrome $\mathrm{P} 450$ inhibitory promiscuity of compounds. J. Chem. Inf. Model. 51, 2482-2495. doi: 10.1021/ci200317s

Dahham, S., Tabana, Y., Iqbal, M., Ahamed, M., Ezzat, M., Majid, A., et al. (2015). The anticancer, antioxidant and antimicrobial properties of the sesquiterpene $\beta$-caryophyllene from the essential oil of Aquilaria crassna. Molecules 20, 11808-11829. doi: 10.3390/molecules200711808
De Petrocellis, L., Ligresti, A., Schiano Moriello, A., Iappelli, M., Verde, R., Stott, C. G., et al. (2013). Non-THC cannabinoids inhibit prostate carcinoma growth in vitro and in vivo: pro-apoptotic effects and underlying mechanisms. Br. J. Pharmacol. 168, 79-102. doi: 10.1111/j.1476-5381.2012.02027.x

Dexanabinol in patients with brain cancer, ClinicalTrials.gov Available at: https:// clinicaltrials.gov/ct2/show/NCT01654497 (Accessed February 27, 2019).

Di Marzo, V., Palmisano, A., Laezza, C., De Petrocellis, L., Bifulco, M., Melck, D., et al. (1998). The endogenous cannabinoid anandamide inhibits human breast cancer cell proliferation. Proc. Natl. Acad. Sci. 95, 8375-8380. doi: 10.1073/ pnas.95.14.8375

Di, P., Guan, L., Sun, L., Li, W., Tang, Y., Liu, G., et al. (2018). ADMET-score-a comprehensive scoring function for evaluation of chemical drug-likeness. Medchemcomm 10, 148-157. doi: 10.1039/C8MD00472B

Dong, J., Wang, N.-N., Yao, Z.-J., Zhang, L., Cheng, Y., Ouyang, D., et al. (2018). ADMETlab: a platform for systematic ADMET evaluation based on a comprehensively collected ADMET database. J. Cheminform. 10, 29. doi: 10.1186/s13321-018-0283-x

Dumitru, C. A., Sandalcioglu, I. E., and Karsak, M. (2018). Cannabinoids in glioblastoma therapy: new applications for old drugs. Front. Mol. Neurosci. 11, 1-7. doi: $10.3389 /$ fnmol.2018.00159

Fidyt, K., Fiedorowicz, A., Strządała, L., and Szumny, A. (2016). B-caryophyllene and B-caryophyllene oxide-natural compounds of anticancer and analgesic properties. Cancer Med. 5, 3007-3017. doi: 10.1002/cam4.816

Fiore, D., Ramesh, P., Proto, M. C., Piscopo, C., Franceschelli, S., Anzelmo, S., et al. (2018). Rimonabant kills colon cancer stem cells without inducing toxicity in normal colon organoids. J. Altern. Complement. Med. 8, 1-15. doi: 10.3389/ fphar.2017.00949

Fowler, C. J. (2015). Delta9-tetrahydrocannabinol and cannabidiol as potential curative agents for cancer: a critical examination of the preclinical literature. Clin. Pharmacol. Ther. 97, 587-596. doi: 10.1002/cpt.84

Fraguas-Sánchez, A. I., Fernández-Carballido, A., and Torres-Suárez, A. I. (2016). Phyto-, endo- and synthetic cannabinoids: promising chemotherapeutic agents in the treatment of breast and prostate carcinomas. Expert Opin. Investig. Drugs 25, 1311-1323. doi: 10.1080/13543784.2016.1236913

Gallotta, D., Nigro, P., Cotugno, R., Gazzerro, P., Bifulco, M., and Belisario, M. A. (2010). Rimonabant-induced apoptosis in leukemia cell lines: activation of caspase-dependent and -independent pathways. Biochem. Pharmacol. 80, 370380. doi: 10.1016/j.bcp.2010.04.023

Gazzerro, P., Malfitano, A. M., Proto, M. C., Santoro, A., Pisanti, S., Caruso, M. G., et al. (2010). Synergistic inhibition of human colon cancer cell growth by the cannabinoid CB1 receptor antagonist rimonabant and oxaliplatin. Oncol. Rep. 23, 171-175. doi: $10.3892 /$ or

Grimaldi, C., Pisanti, S., Laezza, C., Malfitano, A. M., Santoro, A., Vitale, M., et al. (2006). Anandamide inhibits adhesion and migration of breast cancer cells. Exp. Cell Res. 312, 363-73. doi: 10.1016/j.yexcr.2005.10.024

Grotenhermen, F. (2003). Pharmacokinetics and pharmacodynamics of cannabinoids. Clin. Pharmacokinet. 42, 327-360. doi: 10.2165/00003088200342040-00003

Guengerich, F. P. (2008). Cytochrome P450 and chemical toxicology. Chem. Res. Toxicol. 21, 70-83. doi: 10.1021/tx700079z

Guindon, J., and Hohmann, A. G. (2011). The endocannabinoid system and cancer: therapeutic implication. Br. J. Pharmacol. 163, 1447-1463. doi: 10.1111/ j.1476-5381.2011.01327.x

Guzmán, M. (2003). Cannabinoids: potential anticancer agents. Nat. Rev. Cancer 3, 745-755. doi: $10.1038 / \mathrm{nrcl} 188$

Guzmán, M. (2018). Cannabis for the management of cancer symptoms: THC version 2.0? Cannabis Cannabinoid Res. 3, 117-119. doi: 10.1089/can.2018. 0009

Guzmán, M., Duarte, M. J., Blázquez, C., Ravina, J., Rosa, M. C., Galve-Roperh, I., et al. (2006). A pilot clinical study of Delta9-tetrahydrocannabinol in patients with recurrent glioblastoma multiforme. Br. J. Cancer 95, 197-203. doi: 10.1038/sj.bjc.6603236

Hanlon, K. E., Lozano-Ondoua, A. N., Umaretiya, P. J., Symons-Liguori, A. M., Chandramouli, A., Moy, J. K., et al. (2016). Modulation of breast cancer cell viability by a cannabinoid receptor 2 agonist, JWH-015, is calcium dependent. Breast Cancer (Dove Med. Press) 8, 59-71. doi: 10.2147/BCTT. S100393 
Hansen, K., Mika, S., Schroeter, T., Sutter, A., Laak, A., Thomas, S. H., et al. (2009). Benchmark data set for in silico prediction of Ames mutagenicity. J. Chem. Inf. Model. 49, 2077-2081. doi: 10.1021/ci900161g

Hinz, B., and Ramer, R. (2019). Anti-tumour actions of cannabinoids. Br. J. Pharmacol. 176 (10), 1384-1394. doi: 10.1111/bph.14426

Huffman, J., and Marriott, K.-S. (2008). Recent advances in the development of selective ligands for the cannabinoid CB2 receptor. Curr. Top. Med. Chem. 8, 187-204. doi: 10.2174/156802608783498014

Hyun, H. B., Lee, W. S., Go, S. Il, Nagappan, A., Park, C., Han, M. H., et al. (2015). The flavonoid morin from Moraceae induces apoptosis by modulation of Bcl-2 family members and Fas receptor in HCT 116 cells. Int. J. Oncol. 46, 26702678. doi: 10.3892/ijo.2015.2967

Jiang, W., Wang, Y., Sun, W., and Zhang, M. (2017). Morin suppresses astrocyte activation and regulates cytokine release in bone cancer pain rat models. Phytother. Res. 1304, 1298-1304. doi: 10.1002/ptr.5849

Jorgensen, W. L., and Duffy, E. M. (2002). Prediction of drug solubility from structure. Adv. Drug Deliv. Rev. 54, 355-366. doi: 10.1016/S0169-409X(02)00008-X

Jüttler, E., Potrovita, I., Tarabin, V., Prinz, S., Dong-Si, T., Fink, G., et al. (2004). The cannabinoid dexanabinol is an inhibitor of the nuclear factor-kappa B (NF-kB). Neuropharmacology 47, 580-592. doi: 10.1016/j.neuropharm.2004.05.009

Khan, M. I., Soboci, A. A., Brodaczewska, K. K., Zielniok, K., Gajewska, M., Kieda, C., et al. (2018). Involvement of the CB 2 cannabinoid receptor in cell growth inhibition and G0/G1 cell cycle arrest via the cannabinoid agonist WIN 55,212-2 in renal cell carcinoma. BMC Cancer 18, 583. doi: 10.1186/s12885-018-4496-1

Khan, M. I., Sobocinska, A. A., Czarnecka, A. M., Krol, M., Botta, B., and Szczylik, C. (2016). The therapeutic aspects of the endocannabinoid system (ECS) for cancer and their development: from nature to laboratory. Curr. Pharm. Des. 22, 1756-1766. doi: 10.2174/1381612822666151211094901

Kogan, N. M., Bl, C., Alvarez, L., Gallily, R., Schlesinger, M., Guzm, M., et al. (2006). A cannabinoid quinone inhibits angiogenesis by targeting vascular endothelial cells. Mol. Pharmacol. 70, 51-59. doi: 10.1124/mol.105.021089

Kogan, N. M., Rabinowitz, R., Levi, P., Gibson, D., Sandor, P., Schlesinger, M., et al. (2004). Synthesis and antitumor activity of quinonoid derivatives of cannabinoids. J. Med. Chem. 47, 3800-3806. doi: 10.1021/jm040042o

Kogan, N. M., Schlesinger, M., Priel, E., Rabinowitz, R., Berenshtein, E., Chevion, M., et al. (2007). HU-331, a novel cannabinoid-based anticancer topoisomerase II inhibitor. Mol. Cancer Ther. 6, 173-83. doi: 10.1158/1535-7163.MCT-06-0039

Ladin, D. A., Soliman, E., Griffin, L., and Van Dross, R. (2016). Preclinical and clinical assessment of cannabinoids as anti-cancer agents. Front. Pharmacol. 7, 1-18. doi: 10.3389/fphar.2016.00361

Lagunin, A., Filimonov, D., Zakharov, A., Xie, W., Huang, Y., Zhu, F., et al. (2009). Computer-aided prediction of rodent carcinogenicity by PASS and CISOCPSCT. QSAR Comb. Sci. 28, 806-810. doi: 10.1002/qsar.200860192

Li, X., Chen, L., Cheng, F., Wu, Z., Bian, H., Xu, C., et al. (2014). In silico prediction of chemical acute oral toxicity using multi-classification methods. J. Chem. Inf. Model. 54, 1061-1069. doi: 10.1021/ci5000467

Li, X., Du, Z., Wang, J., Wu, Z., Li, W., Liu, G., et al. (2015). In silico estimation of chemical carcinogenicity with binary and ternary classification methods. Mol. Inform. 34, 228-235. doi: 10.1002/minf.201400127

Ligresti, A. (2006). Antitumor activity of plant cannabinoids with emphasis on the effect of cannabidiol on human breast carcinoma. J. Pharmacol. Exp. Ther. 318, 1375-1387. doi: 10.1124/jpet.106.105247

Ligresti, A., De Petrocellis, L., and Di Marzo, V. (2016). From phytocannabinoids to cannabinoid receptors and endocannabinoids: pleiotropic physiological and pathological roles through complex pharmacology. Physiol. Rev. 96, 15931659. doi: 10.1152/physrev.00002.2016

Lipinski, C. A. (2001). Drug-like properties and the causes of poor solubility and poor permeability. J. Pharmacol. Toxicol. Methods 44, 235-249. doi: 10.1016/ S1056-8719(00)00107-6

Liu, W. M., Fowler, D. W., and Dalgleish, A. G. (2010). Cannabis-derived substances in cancer therapy-an emerging anti-inflammatory role for the cannabinoids. Curr. Clin. Pharmacol. 5, 281-287. Available at: http://www.ncbi.nlm.nih.gov/ pubmed/20925645. doi: 10.2174/157488410793352049

López-Valero, I., Saiz-Ladera, C., Torres, S., Hernández-Tiedra, S., GarcíaTaboada, E., Rodríguez-Fornés, F., et al. (2018). Targeting glioma initiating cells with a combined therapy of cannabinoids and temozolomide. Biochem. Pharmacol. 157, 266-274. doi: 10.1016/j.bcp.2018.09.007
Luca, T., Di Benedetto, G., Scuderi, M. R., Palumbo, M., Clementi, S., Bernardini, R., et al. (2009). The CB1/CB2 receptor agonist WIN-55,212-2 reduces viability of human Kaposi's sarcoma cells in vitro. Eur. J. Pharmacol. 616, 16-21. doi: 10.1016/j.ejphar.2009.06.004

Ma, M., Bai, J., Ling, Y., Chang, W., Xie, G., Li, R., et al. (2016). Monoacylglycerol lipase inhibitor JZL184 regulates apoptosis and migration of colorectal cancer cells. Mol. Med. Rep. 13, 2850-2856. doi: 10.3892/mmr.2016.4829

Manera, C., Saccomanni, G., Malfitano, A. M., Bertini, S., Castelli, F., Laezza, C., et al. (2012). Rational design, synthesis and anti-proliferative properties of new CB2 selective cannabinoid receptor ligands: an investigation of the 1,8-naphthyridin-2(1H)-one scaffold. Eur. J. Med. Chem. 52, 284-294. doi: 10.1016/j.ejmech.2012.03.031

Mangini, M., Iaccino, E., Mosca, M. G., Mimmi, S., D’Angelo, R., Quinto, I., et al. (2017). Peptide-guided targeting of GPR55 for anti-cancer therapy. Oncotarget 8, 5179-5195. doi: 10.18632/oncotarget.14121

Marchese Robinson, R. L., Glen, R. C., and Mitchell, J. B. O. (2011). Development and comparison of hERG blocker classifiers: assessment on different datasets yields markedly different results. Mol. Inform. 30, 443-458. doi: 10.1002/minf.201000159

Marshall, A. D., Lagutina, I., and Grosveld, G. C. (2011). PAX3-FOXO1 induces cannabinoid receptor 1 to enhance cell invasion and metastasis. Cancer Res. 71 (24), 7471-7481. doi: 10.1158/0008-5472.CAN-11-0924

Matas, D., Juknat, A., Pietr, M., Klin, Y., and Vogel, Z. (2007). Anandamide protects from low serum-induced apoptosis via its degradation to ethanolamine. J. Biol. Chem. 282, 7885-7892. doi: 10.1074/jbc.M608646200

Mimeault, M., Pommery, N., Wattez, N., Bailly, C., and Hénichart, J. P. (2003). Antiproliferative and apoptotic effects of anandamide in human prostatic cancer cell lines: implication of epidermal growth factor receptor down-regulation and ceramide production. Prostate 56, 1-12. doi: 10.1002/pros.10190

Mohammadpour, F., Nasser, S., Aliebrahimi, S., and Daman, Z. (2017). Antiinvasion effects of cannabinoids agonist and antagonist on human breast cancer stem cells. Iran. J. Pharm. Res. 16, 1479-1486.

Morales, P., and Reggio, P. H. (2017). An update on non-CB1, non-CB2 cannabinoid related G-protein-coupled receptors. Cannabis Cannabinoid Res. 2, 265-273. doi: 10.1089/can.2017.0036

Morales, P., Blasco-Benito, S., Andradas, C., Gómez-Cañas, M., Flores, J. M., Goya, P., et al. (2015). Selective, nontoxic CB2 cannabinoid o-quinone with in vivo activity against triple-negative breast cancer. J. Med. Chem. 58, 2256-2264. doi: 10.1021/acs.jmedchem.5b00078

Morales, P., Hurst, D. P., and Reggio, P. H. (2017a). "Molecular targets of the phytocannabinoids: a complex picture," in Phytocannabinoids unraveling the complex chemistry. Eds. Kinghorn A. D. and Gibbons S. (Switzerland: Springer International Publishing), 103-131. doi: 10.1007/978-3-319-45541-9

Morales, P., Reggio, P. H., and Jagerovic, N. (2017b). An overview on medicinal chemistry of synthetic and natural derivatives of cannabidiol. Front. Pharmacol. 8, 1-18. doi: 10.3389/fphar.2017.00422

Morales, P., Vara, D., Goméz-Cañas, M., Zúñiga, M. C., Olea-Azar, C., Goya, P., et al. (2013). Synthetic cannabinoid quinones: preparation, in vitro antiproliferative effects and in vivo prostate antitumor activity. Eur. J. Med. Chem. 70, 111-119. Available at: http://www.sciencedirect.com/science/article/pii/S0223523413006247 (Accessed October 22, 2013). doi: 10.1016/j.ejmech.2013.09.043

Morell, C., Bort, A., Vara, D., Ramos-Torres, A., Rodríguez-Henche, N., and DíazLaviada, I. (2016). The cannabinoid WIN 55,212-2 prevents neuroendocrine differentiation of LNCaP prostate cancer cells. Prostate Cancer Prostatic Dis. 19, 248-257. doi: 10.1038/pcan.2016.19

Müller, L., Radtke, A., Decker, J., Koch, M., and Belge, G. (2017). The synthetic cannabinoid WIN 55,212-2 elicits death in human cancer cell lines. Anticancer Res. 37, 6341-6345. Available at: http://ar.iiarjournals.org/content/37/11/6341. abstract. doi: 10.21873/anticanres.12086

Munson, A. E., Harris, L. S., Friedman, M. A., Dewey, W. L., and Carchman, R. A. (1975). Antineoplastic activity of cannabinoids. J. Natl. Cancer Inst. 55, $597-$ 602. doi: 10.1093/jnci/55.3.597

Nasser, M. W., Qamri, Z., Deol, Y. S., Smith, D., Shilo, K., Zou, X., et al. (2011). Crosstalk between chemokine receptor CXCR4 and cannabinoid receptor CB 2 in modulating breast cancer growth and invasion. PLoS One 6, 1-9. doi: 10.1371/journal.pone.0023901

Olea-Herrero, N., Vara, D., Malagarie-Cazenave, S., and Díaz-Laviada, I. (2009). Inhibition of human tumour prostate PC-3 cell growth by cannabinoids 
R()-methanandamide and JWH-015: involvement of CB 2. Br. J. Cancer 101, 940-950. doi: 10.1038/sj.bjc.6605248

Ortega, A., Garcia-Hernandez, V. M., Ruiz-Garcia, E., Meneses-Garcia, A., Herrera-Gomez, A., Aguilar-Ponce, J. L., et al. (2016). Comparing the effects of endogenous and synthetic cannabinoid receptor agonists on survival of gastric cancer cells. Life Sci. 165, 56-62. doi: 10.1016/j.lfs.2016.09.010

Paul, R. K., Wnorowski, A., Gonzalez-Mariscal, I., Nayak, S. K., Pajak, K., Moaddel, R., et al. (2014). (R,R')-4'-methoxy-1-naphthylfenoterol targets GPR55mediated ligand internalization and impairs cancer cell motility. Biochem. Pharmacol. 87, 547-561. doi: 10.1016/j.bcp.2013.11.020

Pellati, F., Borgonetti, V., Brighenti, V., Biagi, M., Benvenuti, S., and Corsi, L. (2018). Cannabis sativa L. and nonpsychoactive cannabinoids: their chemistry and role against oxidative stress, inflammation, and cancer. BioMed Res. Int. 2018, 1-15. doi: 10.1155/2018/1691428

Pisanti, S., Picardi, P., D’Alessandro, A., Laezza, C., and Bifulco, M. (2013). The endocannabinoid signaling system in cancer. Trends Pharmacol. Sci. 34, 273-282.

Powles, T., Te Poele, R., Shamash, J., Chaplin, T., Propper, D., Joel, S., et al. (2005). Cannabis-induced cytotoxicity in leukemic cell lines: the role of the cannabinoid receptors and the MAPK pathway. Blood 105, 1214-1221. doi: 10.1182/blood-2004-03-1182

Preet, A., Qamri, Z., Nasser, M. W., Prasad, A., Shilo, K., Zou, X., et al. (2011). Cannabinoid receptors, CB1 and CB2, as novel targets for inhibition of nonsmall cell lung cancer growth and metastasis. Cancer Prev. Res. (Phila.) 4, 65-75. doi: 10.1158/1940-6207.CAPR-10-0181

Proto, M. C., Fiore, D., Piscopo, C., Franceschelli, S., Laezza, C., Lauro, G. et al. (2017). Inhibition of Wnt/ $\beta$-catenin pathway and histone acetyltransferase activity by rimonabant: a therapeutic target for colon cancer. Sci. Rep. 7, 11678. doi: 10.1038/s41598-017-11688-x

Qamri, Z., Preet, A., Nasser, M. W., Bass, C. E., Leone, G., Barsky, S. H., et al. (2009). Synthetic cannabinoid receptor agonists inhibit tumor growth and metastasis of breast cancer. Mol. Cancer Ther. 8, 3117-3129. doi: 10.1158/15357163.MCT-09-0448

Quintana, P. G., García Liñares, G., Chanquia, S. N., Gorojod, R. M., Kotler, M. L., and Baldessari, A. (2016). Improved enzymatic procedure for the synthesis of anandamide and $\mathrm{N}$-fatty acylalkanolamine analogues: a combination strategy to antitumor activity. European J. Org. Chem. 2016, 518-528. doi: 10.1002/ ejoc. 201501263

Ravi, J., Elbaz, M., Wani, N. A., Nasser, M. W., and Ganju, R. K. (2016). Cannabinoid receptor-2 agonist inhibits macrophage induced EMT in non-small cell lung cancer by downregulation of EGFR pathway. Mol. Carcinog. 55, 2063-2076. doi: 10.1002/mc.22451

Refolo, M. G., D’Alessandro, R., Malerba, N., Laezza, C., Bifulco, M., Messa, C., et al. (2015). Anti proliferative and pro apoptotic effects of flavonoid quercetin are mediated by CB1 receptor in human colon cancer cell lines. J. Cell. Physiol. 230, 2973-2980. doi: 10.1002/jcp.25026

Ruiz, L., Miguel, A., and Diaz-Laviada, I. (1999). 9-Tetrahydrocannabinol induces apoptosis in human prostate PC-3 cells via a receptor-independent mechanism. FEBS Lett. 458, 400-404. Available at: http://ovidsp.ovid.com/ovidweb.cgi?T= JS\&PAGE=reference $\& D=$ emed $4 \& N E W S=N \& A N=1999322167$. doi: $10.1016 /$ S0014-5793(99)01073-X

Sánchez, M. G., Sánchez, A. M., Ruiz-Llorente, L., and Díaz-Laviada, I. (2003). Enhancement of androgen receptor expression induced by (R)-methanandamide in prostate LNCaP cells. FEBS Lett. 555, 561-566. doi: 10.1016/S0014-5793 (03)01349-8

Santoro, A., Pisanti, S., Grimaldi, C., Izzo, A. A., Borrelli, F., Proto, M. C. et al. (2009). Rimonabant inhibits human colon cancer cell growth and reduces the formation of precancerous lesions in the mouse colon. Int. J. Cancer 1003, 9961003. doi: $10.1002 /$ ijc. 24483

Sarnataro, D., Pisanti, S., Santoro, A., Gazzerro, P., Malfitano, A. M., Laezza, C., et al. (2006). The cannabinoid CB1 receptor antagonist rimonabant (SR141716) Inhibits human breast cancer cell proliferation through a lipid raft-mediated mechanism. Mol. Pharmacol. 70, 1298-1306. doi: 10.1124/mol.106.025601

Scott, K. A., Dalgleish, A. G., and Liu, W. M. (2017). Anticancer effects of phytocannabinoids used with chemotherapy in leukaemia cells can be improved by altering the sequence of their administration. Int. J. Oncol. 51, 369-377. doi: 10.3892/ijo.2017.4022

Singer, E., Judkins, J., Salomonis, N., Matlaf, L., Soteropoulos, P., McAllister, S., et al. (2015). Reactive oxygen species-mediated therapeutic response and resistance in glioblastoma. Cell Death Dis. 6, e1601-e1611. doi: 10.1038/ cddis. 2014.566

Solbrig, M. V., Fan, Y., Hermanowicz, N., Morgese, M. G., and Giuffrida, A. (2010). A synthetic cannabinoid agonist promotes oligodendrogliogenesis during viral encephalitis in rats. Exp. Neurol. 226, 231-241. doi: 10.1016/j. expneurol.2010.09.003

Soliman, E., and Van Dross, R. (2016). Anandamide-induced endoplasmic reticulum stress and apoptosis are mediated by oxidative stress in nonmelanoma skin cancer: receptor-independent endocannabinoid signaling. Mol. Carcinog. 55, 1807-1821. doi: $10.1002 / \mathrm{mc} .22429$

Sreevalsan, S., Joseph, S., Jutooru, I., Chadalapaka, G., and Safe, S. H. (2011). Induction of apoptosis by cannabinoids in prostate and colon cancer cells is phosphatase dependent. Anticancer Res. 31, 3799-3807. Available at: http:// www.embase.com/search/results? subaction=viewrecord $\&$ from=export\&i $\mathrm{d}=\mathrm{L} 363057496$.

Stout, S. M., and Cimino, N. M. (2014). Exogenous cannabinoids as substrates, inhibitors, and inducers of human drug metabolizing enzymes: a systematic review. Drug Metab. Rev. 46, 86-95. doi: 10.3109/03602532.2013.849268

Striem, S., Bar-Joseph, A., Berkovitch, Y., and Biegon, A. (1997). Interaction of dexanabinol (HU-211), a novel NMDA receptor antagonist, with the dopaminergic system. Eur. J. Pharmacol. 338, 205-213. doi: 10.1016/S00142999(97)81923-1

Takeda, S., Himeno, T., Kakizoe, K., Okazaki, H., Okada, T., Watanabe, K., et al. (2017). Cannabidiolic acid-mediated selective down-regulation of c-fos in highly aggressive breast cancer MDA-MB-231 cells: possible involvement of its down-regulation in the abrogation of aggressiveness. J. Nat. Med. 71, 286-291. doi: 10.1007/s11418-016-1030-0

Thakur, G., Nikas, S., and Makriyannis, A. (2005). CB1 cannabinoid receptor ligands. Mini Rev. Med. Chem. 5, 631-640. doi: 10.2174/1389557054368772

TN-TC11G (THC+CBD) Combination with temozolomide and radiotherapy in patients with newly-diagnosed glioblastoma, ClinicalTrials.gov. Available at: https://clinicaltrials.gov/ct2/show/NCT03529448?term=cannabinoids\&cond= Cancer\&draw $=3 \&$ rank $=16$ (Accessed February 28, 2019).

Torres, S., Lorente, M., Rodríguez-Fornés, F., Hernández-Tiedra, S., Salazar, M., García-Taboada, E., et al. (2011). A combined preclinical therapy of cannabinoids and temozolomide against glioma. Mol. Cancer Ther. 10, 90-103. doi: 10.1158/1535-7163.MCT-10-0688

Velasco, G., Sánchez, C., and Guzmán, M. (2012). Towards the use of cannabinoids as antitumour agents. Nat. Rev. Cancer 12, 436-444. doi: 10.1038/nrc3247

Velasco, G., Sánchez, C., and Guzmán, M. (2016). Anticancer mechanisms of cannabinoids. Curr. Oncol. 23, S23-S32. doi: 10.3747/co.23.3080

Vemuri, V. K., and Makriyannis, A. (2015). Medicinal chemistry of cannabinoids. Clin. Pharmacol. Ther. 97, 553-558. doi: 10.1002/cpt.115

Ware, M. A., Daeninck, P., and Maida, V. (2008). A review of nabilone in the treatment of chemotherapy-induced nausea and vomiting. Ther. Clin. Risk Manag. 4, 99-107. Available at: http://www.embase.com/search/results?subaction=viewre cord\&from=export\&id=L351460935. doi: 10.2147/TCRM.S1132

Wasilewski, A., Krajewska, U., Owczarek, K., Lewandowska, U., and Fichna, J. (2017). Fatty acid amide hydrolase (FAAH) inhibitor PF-3845 reduces viability, migration and invasiveness of human colon adenocarcinoma Colo205 cell line: an in vitro study. Acta Biochim. Pol. 64, 519-525. doi: 10.18388/ abp.2017_1520

Winkler, K., Merkord, J., Hinz, B., Ramer, R., Dithmer, S., and Ivanov, I. (2016). Fatty acid amide hydrolase inhibitors confer anti-invasive and antimetastatic effects on lung cancer cells. Oncotarget 7, 15047-15064. doi: 10.18632/oncotarget.7592

Xian, X., Huang, L., Zhang, B., Wu, C., Cui, J., and Wang, Z. (2016). WIN 55,212-2 inhibits the epithelial mesenchymal transition of gastric cancer cells via COX-2 signals. Cell. Physiol. Biochem. 39, 2149-2157. doi: 10.1159/ 000447910

Xu, C., Cheng, F., Chen, L., Du, Z., Li, W., Liu, G., et al. (2012). In silico prediction of chemical Ames mutagenicity. J. Chem. Inf. Model. 52, 2840-2847. doi: $10.1021 / \mathrm{ci} 300400 \mathrm{a}$

Xu, D., Wang, J., Zhou, Z., He, Z., and Zhao, Q. (2015). Cannabinoid WIN55, 212-2 induces cell cycle arrest and inhibits the proliferation and migration of human BEL7402 hepatocellular carcinoma cells. Mol. Med. Rep. 12, 7963-7970. doi: $10.3892 / \mathrm{mmr} .2015 .4477$

Yamada, K., Rice, K. C., Flippen-Anderson, J. L., Eissenstat, M. A., Ward, S. J., Johnson, M. R., et al. (1996). (Aminoalkyl)indole isothiocyanates as potential 
electrophilic affinity ligands for the brain cannabinoid receptor. J. Med. Chem. 39, 1967-1974. doi: 10.1021/jm950932r

Yang, H., Lou, C., Sun, L., Li, J., Cai, Y., Wang, Z., et al. (2018). admetSAR 2.0: web-service for prediction and optimization of chemical ADMET properties. Bioinformatics, 1067-1069. doi: 10.1093/bioinformatics/bty707

Zendulka, O., Dovrtelová, G., Nosková, K., Turjap, M., Sulcová, A., Hanus, L., et al. (2016). Cannabinoids and cytochrome P450 interactions. Curr. Drug Metab. 17, 206-226. doi: 10.4161/auto.5223

Zhang, J., Zhang, S., Liu, Y., Su, M., Ling, X., Liu, F., et al. (2018a). Combined CB2 receptor agonist and photodynamic therapy synergistically inhibit tumor growth in triple negative breast cancer. Photodiagnosis Photodyn. Ther. 24, 185191. doi: $10.1016 /$ j.pdpdt.2018.09.006

Zhang, S., Jia, N., Shao, P., Tong, Q., Xie, X.-Q., and Bai, M. (2014). Target-selective phototherapy using a ligand-based photosensitizer for type 2 cannabinoid receptor. Chem. Biol. 21, 338-44. doi: 10.1016/j.chembiol.2014.01.009

Zhang, Y., Zheng, W., Shen, K., and Shen, W. (2018b). D9-Tetrahydrocannabinol inhibits epithelial-mesenchymal transition and metastasis by targeting matrix metalloproteinase-9 in endometrial cancer. Oncol. Lett. 15, 8527-8535. doi: 10.3892/ol.2018.8407

Zhu, H., Martin, T. M., Ye, L., Sedykh, A., Young, D. M., and Tropsha, A. (2009). Quantitative structure-activity relationship modeling of rat acute toxicity by oral exposure. Chem. Res. Toxicol. 22, 1913-1921. doi: 10.1021/tx900189p

Conflict of Interest Statement: The authors declare that the research was conducted in the absence of any commercial or financial relationships that could be construed as a potential conflict of interest.

Copyright () 2019 Morales and Jagerovic. This is an open-access article distributed under the terms of the Creative Commons Attribution License (CC BY). The use, distribution or reproduction in other forums is permitted, provided the original author(s) and the copyright owner(s) are credited and that the original publication in this journal is cited, in accordance with accepted academic practice. No use, distribution or reproduction is permitted which does not comply with these terms. 